\title{
Synthesis of Some Novel Carboxylic Acids and Insecticidal Activity of Their Esters ${ }^{\dagger}$
}

\author{
Katsuhide OKada, Fumiharu Kryooka, Eiji NaKanishi, \\ Masachika Hrrano, ${ }^{*}$ Isao OHNo, ${ }^{*}$ Noritada Matsuo* \\ and Masanao MatsuI \\ Department of Agricultural Chemistry, The University of Tokyo, \\ Bunkyo-ku, Tokyo 113, Japan \\ *Research Department, Pesticide Division. Sumitomo Chemical Co., Ltd., \\ Takarazuka, Hyogo 665, Japan \\ Received May 1, 1980
}

\begin{abstract}
Various novel acyclic carboxylic acids were prepared and some of their 3-phenoxybenzyl esters were found to have slight insecticidal activity.
\end{abstract}

One of the useful acid moieties of a number of synthetic pyrethroids ${ }^{1)}$ is $\alpha$-isopropyl-4chlorophenylacetic acid. ${ }^{2)}$ This paper reports the synthesis of some new carboxylic acids in which the phenyl or the isopropyl group of $\alpha$ isopropylphenylacetic acid is replaced with other groups, and the insecticidal activity of their 3-phenoxybenzyl esters.

Methyl 3-pentenoate ${ }^{3)}$ and ethyl 3-hexenoate $^{3)}$ were alkylated at $\alpha$-position with ethyl or isopropyl halides, and the alkylated products were hydrolyzed to acids $(\mathbf{1}, \mathbf{2}, \mathbf{3})$ (Fig. 1). The acids were analyzed by PMR.

Alkylation of ethyl crotonate with isopropyl iodide in the presence of LDA gave the ester 4 , but hydrolysis of $\mathbf{4}$ gave a mixture of acids 5 and $6(2: 3)$. Alkylation of tert-butyl crotonate in the presence of sodium amide gave a mixture of 7 and $8(2: 1)$, and when $0.8 \mathrm{~mol} \mathrm{eq}$. of the base was used the ratio of 7 and 8 was 3:1 (Fig. 1).

The nitrile 13, prepared by alkylation of 12 , was hydrolyzed to the carboxylic acid 14. The bromide 11 was prepared from the ester 9 via the alcohol $\mathbf{1 0}$ and alternatively bromination of dimethylbutene by NBS gave the same bromide.

This bromide 11 was converted to the nitrile

+ Studies on Chrysanthemic Acid. Part XXIX. For Part XXVIII, see ref. 4.

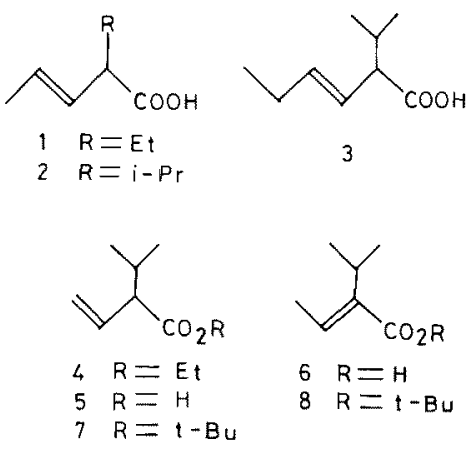

FIG. 1.

12 by the usual method (Fig. 2).

The above acids $(\mathbf{1}, \mathbf{2}, \mathbf{3}, \mathbf{5}, \mathbf{6}, \mathbf{1 4})$ were converted to acid chlorides and esterified with 3-phenoxybenzyl alcohol (Fig. 3).

The esters 16 and 17 were converted to the corresponding dichlorocyclopropane derivatives $\mathbf{2 0}$ and $\mathbf{2 1}$ or oxidized to the corresponding epoxides 22 and 23 respectively (Fig. 4).

Table I shows the insecticidal activities of nine 3-phenoxybenzyl carboxylates on mosquitoes and houseflies.

Compounds 16 and 17 were active on both insects and the esters 18 (a mixture of 5 and 6 ) showed a low activity on mosquitoes. 


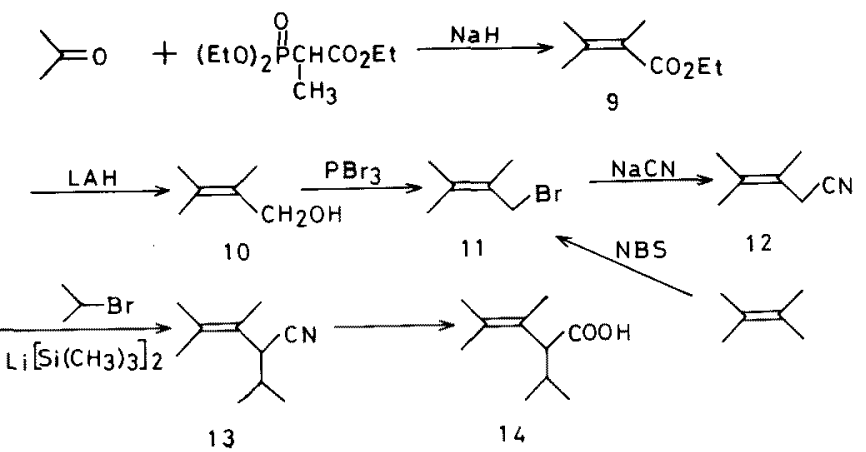

FIG. 2 .

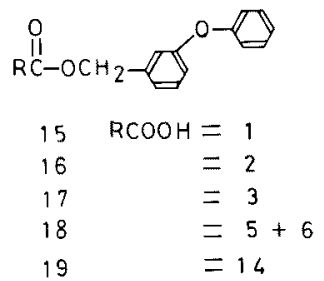

Fig. 3

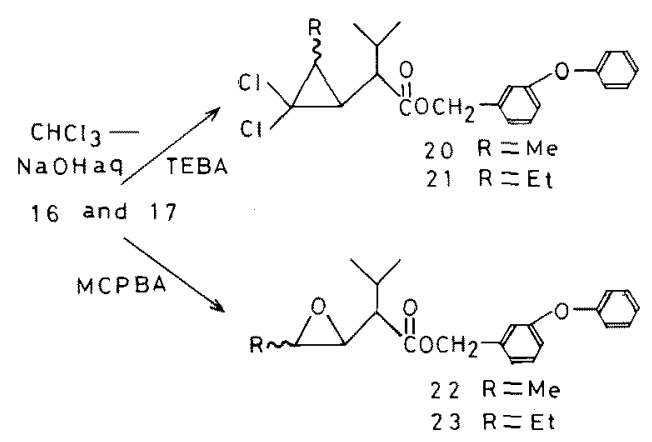

FIG. 4.

\section{EXPERIMENTAL}

All boiling points were uncorrected. IR spectra were referred to films on a JASCO IRA-1 spectrometer. PMR spectra were recorded on a JEOL (JNM-MH 100) spectrometer or on a Hitachi R-24A spectrometer with TMS as an internal standard.

Methyl 2-ethyl-3-pentenoate. Methyl 3-pentenoate ${ }^{3 \text { ) }}$ $(4.4 \mathrm{~g})$ was added to a solution of sodium amide prepared from sodium metal $(0.9 \mathrm{~g})$ in liq ammonia over $30 \mathrm{~min}$ and the solution was stirred for additional $30 \mathrm{~min}$.

Ethyl bromide $(8.8 \mathrm{ml})$ was added dropwise to the above solution and after the solution was stirred for $1 \mathrm{hr}$, ammonium chloride ( $1.72 \mathrm{~g}$ ) was added. The solution was left to stand overnight at room temperature and ice-cooled $5 \% \mathrm{HCl}$ solution was added. The solution was extracted with ether and the extract was washed with sat $\mathrm{NaHCO}_{3}$
TABLE I. TOXICITIES OF 3-PHENOXYBENZYL Carboxylates to Mosquitoes AND HOUSEFLIES

\begin{tabular}{|c|c|c|c|c|}
\hline \multirow{3}{*}{ Compounds } & \multicolumn{4}{|c|}{ Mortality } \\
\hline & \multicolumn{2}{|c|}{ Mosquitoes } & \multicolumn{2}{|c|}{ Houseflies } \\
\hline & $0.5 \mathrm{ppm}$ & $5 \mathrm{ppm}$ & $50 \mathrm{ppm}$ & $500 \mathrm{ppm}$ \\
\hline 15 & 0 & 0 & 0 & 0 \\
\hline 16 & 13.3 & 95.0 & 0 & 100 \\
\hline 17 & 10.0 & 61.7 & 0 & 100 \\
\hline 18 & 0 & 86.7 & 0 & 0 \\
\hline 19 & 0 & 0 & 0 & 0 \\
\hline 20 & 0 & 1.7 & 0 & 0 \\
\hline 21 & 0 & 0 & 0 & 0 \\
\hline 22 & 0 & 0 & 0 & 0 \\
\hline 23 & 0 & 0 & 0 & 0 \\
\hline $\begin{array}{l}\text { Phenothrin* } \\
\left(\mathrm{LC}_{50}\right)\end{array}$ & \multicolumn{2}{|c|}{$0.06 \mathrm{ppm}$} & \multicolumn{2}{|c|}{$18.0 \mathrm{ppm}$} \\
\hline
\end{tabular}

solution, brine and dried over $\mathrm{MgSO}_{4}$. The solution was concentrated and the residue was distilled to give $3.4 \mathrm{~g}$ $(60 \%)$ of methyl 2-ethyl-3-pentenoate, bp $89 \sim 92^{\circ} \mathrm{C}$ (45 $\mathrm{mmHg}) ; n_{\mathrm{D}}^{24} 1.4266 ;$ IR $v_{\max } \mathrm{cm}^{-1}: 1745,1360 ;$ PMR $(60$ $\left.\mathrm{MHz}, \mathrm{CDCl}_{3}\right) \delta: 0.9\left(3 \mathrm{H}, \mathrm{t}, J=7 \mathrm{~Hz}, \mathrm{C}-\mathrm{CH}_{3}\right), 1.1 \sim 1.6$ $\left(2 \mathrm{H}, \mathrm{m}, \mathrm{CH}_{2}\right), 1.7\left(3 \mathrm{H}, \mathrm{d}, J=3 \mathrm{~Hz}, \mathrm{CH}_{3}-\mathrm{C}=\mathrm{C}\right), 2.9(1 \mathrm{H}$, $\mathrm{m}, \mathrm{CH}), 3.7\left(3 \mathrm{H}, \mathrm{s}, \mathrm{CO}_{2} \mathrm{CH}_{3}\right), 5.4 \sim 5.7(2 \mathrm{H}, \mathrm{m}, \mathrm{CH}=\mathrm{CH})$.

Methyl 2-isopropyl-3-pentenoate. Methyl 3-pentenoate $(7.47 \mathrm{~g})$ was alkylated with isopropyl iodide $(12.25 \mathrm{~g})$ in a manner similar to that described for the preparation of methyl 2-ethyl-3-pentenoate to give $6.95 \mathrm{~g} \mathrm{(68 \% )} \mathrm{of} \mathrm{methyl}$ 2-isopropyl-3-pentenoate, bp $80 \sim 85^{\circ} \mathrm{C}(50 \mathrm{mmHg}) ; n_{D}^{25}$ 1.4275; IR $v_{\text {max }} \mathrm{cm}^{-1}: 1745,1440$; PMR $\left(60 \mathrm{MHz}, \mathrm{CCl}_{4}\right) \delta$ : 0.85 and 0.96 (each $\left.3 \mathrm{H}, \mathrm{d}, J=6 \mathrm{~Hz},\left(\mathrm{CH}_{3}\right)_{2}\right), 1.7(3 \mathrm{H}, \mathrm{d}$, $\left.J=4 \mathrm{~Hz}, \mathrm{C}=\mathrm{C}-\mathrm{CH}_{3}\right), 1.9 \sim 2.3\left(1 \mathrm{H}, \mathrm{m}, \mathrm{CHMe}_{2}\right), 2.7(1 \mathrm{H}$, d-d, $\left.J=7 \mathrm{~Hz}, \quad \mathrm{CH}-\mathrm{CO}_{2} \mathrm{Me}\right), \quad 3.7\left(3 \mathrm{H}, \mathrm{s}, \mathrm{CO}_{2} \mathrm{CH}_{3}\right)$, 5.4 $5.7(2 \mathrm{H}, \mathrm{m}, \mathrm{CH}=\mathrm{CH})$. 
2-Ethyl-3-pentenoic acid (1). Methyl 2-ethyl-3pentenoate $(1.6 \mathrm{~g})$ was dissolved in methanol $(4 \mathrm{~g})$ containing sodium hydroxide $(0.43 \mathrm{~g})$ and the solution was left to stand overnight at room temperature. The solution was poured into water and the solution was washed with ether. The aqueous solution was acidified with $5 \% \mathrm{HCl}$ solution and extracted with ether. The extract was dried over $\mathrm{Na}_{2} \mathrm{SO}_{4}$ and concentrated to give $0.80 \mathrm{~g}(56 \%)$ of 1 ; PMR $\left(60 \mathrm{MHz}, \mathrm{CDCl}_{3}\right) \delta: 0.9\left(3 \mathrm{H}, \mathrm{t}, J=7 \mathrm{~Hz}, \mathrm{C}-\mathrm{CH}_{3}\right), 1.1 \sim 1.6$ $\left(2 \mathrm{H}, \mathrm{m}, \mathrm{CH}_{2}\right), 1.7\left(3 \mathrm{H}, \mathrm{d}, J=4 \mathrm{~Hz}, \mathrm{CH}_{3}-\mathrm{C}=\mathrm{C}\right), 2.9(1 \mathrm{H}$, $\mathrm{m}, \mathrm{CH}), 5.4 \sim 5.7(2 \mathrm{H}, \mathrm{m}, \mathrm{CH}=\mathrm{CH}), 10.5(1 \mathrm{H}, \mathrm{bs}$, $\mathrm{COOH})$.

2-Isopropyl-3-pentenoic acid (2). Methyl 2-isopropyl-3pentenoate was treated as described for the acid 1 to give $1.78 \mathrm{~g}(56 \%)$ of 2 ; PMR $\left(60 \mathrm{MHz}, \mathrm{CCl}_{4}\right) \delta: 0.85$ and 0.96 (each $\left.3 \mathrm{H}, \mathrm{d}, J=6 \mathrm{~Hz},\left(\mathrm{CH}_{3}\right)_{2}\right), 1.7(3 \mathrm{H}, \mathrm{d}, J=4 \mathrm{~Hz}$, $\left.\mathrm{CH}_{3}-\mathrm{C}=\mathrm{C}\right), 1.9 \sim 2.4\left(1 \mathrm{H}, \mathrm{m}, \mathrm{CHMe} \underline{H}_{2}\right), 2.7(1 \mathrm{H}, \mathrm{d}-\mathrm{d}, J=7$ $\mathrm{Hz}$ and $\left.1 \mathrm{~Hz}, \mathrm{CH}-\mathrm{CO}_{2}\right), 5.4 \sim 5.7(2 \mathrm{H}, \mathrm{m}, \mathrm{CH}=\mathrm{CH}), 10.5$ ( $\mathrm{H}, \mathrm{bs}, \mathrm{COOH})$.

Ethyl 2-isopropyl-3-hexenoate. Ethyl 3-hexenoate ${ }^{3)}$ $(29.9 \mathrm{~g})$ and isopropyl iodide $(42.8 \mathrm{~g})$ were treated as described for methyl 2-ethyl-3-pentenoate

Distillation of the crude product gave $29.7 \mathrm{~g}(77 \%)$ of ethyl 2-isopropyl-3-pentenoate, bp $110 \sim 117^{\circ} \mathrm{C} \quad(48$ $\mathrm{mmHg})$; PMR $\left(60 \mathrm{MHz}, \mathrm{CCl}_{4}\right) \delta: 0.8 \sim 1.1(9 \mathrm{H}, \mathrm{m}$, $\left.\mathrm{CH}_{3} \times 3\right), 1.23\left(3 \mathrm{H}, \mathrm{t}, J=7 \mathrm{~Hz}, \mathrm{CO}_{2} \mathrm{CH}_{2} \mathrm{CH}_{3}\right), 1.8 \sim 2.3$ $\left(3 \mathrm{H}, \mathrm{m}, \mathrm{CH}_{2}-\mathrm{C}=\mathrm{C}\right.$ and $\left.\mathrm{CHMe}_{2}\right), 2.55(\overrightarrow{1 \mathrm{H}}, \mathrm{d}-\mathrm{d}, J=$ $8 \mathrm{~Hz}$ and $\left.1 \mathrm{~Hz}, \mathrm{CH}-\mathrm{CO}_{2} \mathrm{Et}\right), 4.15(2 \mathrm{H}, \mathrm{q}, J=7 \mathrm{~Hz}$, $\left.\mathrm{CO}_{2} \mathrm{CH}_{2} \mathrm{CH}_{3}\right), 3.4 \sim 3.65(2 \mathrm{H}, \mathrm{m}, \mathrm{CH}=\mathrm{CH})$.

2-Isopropyl-3-hexenoic acid (3). Ethyl 2-jsopropyl-3hexenoate $(29.7 \mathrm{~g})$ was treated as described for the acid 1 to give $18.4 \mathrm{~g}(72 \%)$ of 3 , PMR $\left(60 \mathrm{MHz}, \mathrm{CCl}_{4}\right) \delta: 0.8 \sim 1.3$ $\left(9 \mathrm{H}, \mathrm{m}, \mathrm{CH}_{3} \times 3\right), 1.8 \sim 2.3\left(3 \mathrm{H}, \mathrm{m}, \mathrm{CH}_{2}-\mathrm{C}=\mathrm{C}\right.$ and $\left.\mathrm{CHMe}_{2}\right), 2.6(1 \mathrm{H}, \mathrm{d}-\mathrm{d}, J=8 \mathrm{~Hz}$ and $\mathrm{I} \mathrm{Hz}), 5.4 \sim 5.7(2 \mathrm{H}$, $\mathrm{m}, \mathrm{CH}=\mathrm{CH}), 11.9(1 \mathrm{H}, \mathrm{s}, \mathrm{COOH})$.

Ethyl 2-isopropyl-3-butenoate (4). HMPA (8.7g) was added to lithium diisopropylamide in THF $(40 \mathrm{ml})$ prepared from diisopropylamine $(9 \mathrm{~g})$ and $n$-butyllithium $(33.7 \mathrm{ml}, 1.43 \mathrm{M})$ at $-70^{\circ} \mathrm{C}$. After $30 \mathrm{~min}$ ethyl crotonate $(5 \mathrm{~g})$ in THF $(20 \mathrm{ml})$ was added to the solution under stirring. After $10 \mathrm{~min}$ isopropyl iodide $(8.95 \mathrm{~g})$ in THF $(20 \mathrm{ml})$ was added to the above solution and the solution was stirred for $3 \mathrm{hr}$ at $-70^{\circ} \mathrm{C}$.

Ammonium chloride $(10 \mathrm{~g})$ was added and the solution was poured into ice-water. The solution was extracted with ether three times and the extract was washed by $2.5 \% \mathrm{HCl}$ aq. solution, water and dried over $\mathrm{MgSO}_{4}$. The solution was concentrated and the residue was distilled to give $3.60 \mathrm{~g}$ of $4(53 \%)$, bp $75 \sim 85^{\circ} \mathrm{C}(50 \mathrm{mmHg})$; PMR $(60$ $\mathrm{MHz}, \mathrm{CDCl}_{3}$ ) $\delta: 0.85$ and 0.96 (each $3 \mathrm{H}, \mathrm{d}, J=6 \mathrm{~Hz}$, $\left.\left(\mathrm{CH}_{3}\right)_{2}\right) .1 .25\left(3 \mathrm{H}, \mathrm{t}, J=8 \mathrm{~Hz}, \mathrm{CO}_{2} \mathrm{CH}_{2} \mathrm{CH}_{3}\right), 1.8 \sim 2.3$ $(1 \mathrm{H}, \mathrm{m}, \mathrm{CHMe} 2), 2.7(1 \mathrm{H}, \mathrm{d}-\mathrm{d}, J=8 \overline{\mathrm{Hz}}$ and $1 \mathrm{~Hz}$, $\mathrm{CHCO}_{2} \mathrm{Et}$ ), $4.2\left(2 \mathrm{H}, \mathrm{q}, J=8 \mathrm{~Hz}, \mathrm{CO}_{2} \mathrm{CH}_{2} \mathrm{CH}_{3}\right), 4.95 \sim 5.3$ $\left(2 \mathrm{H}, \mathrm{m}, \mathrm{CH}_{2}=\mathrm{C}\right), 5.60 \sim 6.1(1 \mathrm{H}, \mathrm{m}, \mathrm{C}=\mathrm{CH})$.

Hydrolysis of ethyl 2-isopropyl-3-butenoate (4). The ester $4(3.60 \mathrm{~g})$ was hydrolyzed with methanolic $\mathrm{NaOH}$. Based on PMR analysis the product was found to be a mixture $(1.80 \mathrm{~g})$ of 2-isopropyl-3-butenoic acid (5) and 2isopropyl-2-butenoic acid (6) in the ratio of $2: 3$. PMR $(60$ $\mathrm{MHz}, \mathrm{CDCl}_{3}$ ) $\delta: 0.90$ and 1.05 (each $3 \mathrm{H}, \mathrm{d}, J=4 \mathrm{~Hz}$, $\left.\mathrm{C}-\mathrm{C}\left(\mathrm{CH}_{3}\right)_{2}\right), 1.2\left(6 \mathrm{H}, \mathrm{d}, J=7 \mathrm{~Hz}, \quad \mathrm{C}=\mathrm{C}-\mathrm{C}\left(\mathrm{CH}_{3}\right)_{2}\right)$, $1.7 \sim 2.4(1 \mathrm{H}, \mathrm{m}, \mathrm{CHMe}), \quad 1.85(3 \mathrm{H}, \mathrm{d}, J=7 \mathrm{~Hz}$, $\left.\mathrm{CH}_{3}-\mathrm{C}=\mathrm{C}\right), 2.6 \sim 3.2(1 \mathrm{H}, \mathrm{d}-\mathrm{d}, J=8 \mathrm{~Hz}$ and $1 \mathrm{~Hz}$, $\left.\mathrm{C}=\mathrm{C}-\mathrm{CHCO}_{2} \mathrm{H}\right), 5.0 \sim 5.35\left(2 \mathrm{H}, \mathrm{m}, \mathrm{CH}_{2}=\mathrm{C}\right), 5.60 \sim 6.1$ $\left(1 \mathrm{H}, \mathrm{m}, \mathrm{CH}_{2}=\mathrm{CH}\right), 6.95\left(1 \mathrm{H}, \mathrm{q}, J=7 \mathrm{~Hz}, \mathrm{CH}_{3} \mathrm{CH}=\mathrm{C}\right)$, $10.4(1 \mathrm{H}, \mathrm{bs}, \mathrm{COOH})$

Alkylation of tert-butyl crotonate. tert-Butyl crotonate $(5 \mathrm{~g})$ was alkylated with isopropyl iodide in the presence of $\mathrm{NaNH}_{2}$, and the crude product was distilled. Based on PMR analysis the distillate was found to be a mixture $(1.42 \mathrm{~g}, 22 \%$ ) of tert-butyl 2-isopropyl-3-butenoate (7) and tert-butyl 2-isopropyl-2-butenoate (8) in the ratio of $2: 1$. bp $85 \sim 95^{\circ} \mathrm{C}(50 \mathrm{mmHg}) ; n_{\mathrm{D}}^{25} 1.4291$; IR $v_{\max } \mathrm{cm}^{-1}: 1740$ 1720, 1650; PMR $\left(60 \mathrm{MHz}, \mathrm{CDCl}_{3}\right) \delta: 0.85$ and 0.95 (each $\left.3 \mathrm{H}, \mathrm{d}, J=4 \mathrm{~Hz}, \mathrm{CC}\left(\mathrm{CH}_{3}\right)_{2}\right), 1.15(6 \mathrm{H}, \mathrm{d}, J=7 \mathrm{~Hz}$, $\left.\mathrm{C}=\mathrm{CC}\left(\mathrm{CH}_{3}\right)_{2}\right), 1.45\left(9 \mathrm{H}, \mathrm{s},\left(\mathrm{CH}_{3}\right)_{3}\right), 1.47\left(9 \mathrm{H}, \mathrm{s},\left(\mathrm{CH}_{3}\right)_{3}\right)$, $1.75\left(3 \mathrm{H}, \mathrm{d}, J=7 \mathrm{~Hz}, \mathrm{CH}_{3} \mathrm{C}=\mathrm{C}\right), 1.7 \sim 2.1(1 \mathrm{H}, \mathrm{m}$, $\left.\mathrm{CHMe}_{2}\right), 2.6\left(1 \mathrm{H}, \mathrm{d}-\mathrm{d}, J=8 \mathrm{~Hz}\right.$ and $1 \mathrm{~Hz}, \mathrm{C}=\mathrm{CCHCO}_{2} t^{-}$ $\mathrm{Bu}), 4.9 \sim 5.3\left(2 \mathrm{H}, \mathrm{m}, \mathrm{CH}_{2}=\mathrm{C}\right), 5.55 \sim 6.1(1 \mathrm{H}, \mathrm{m}, \mathrm{CH}$ $\left.=\mathrm{CH}_{2}\right), 6.55\left(1 \mathrm{H}, \mathrm{q}, J=7 \mathrm{~Hz}, \mathrm{CH}_{3} \mathrm{CH}=\mathrm{C}\right)$.

Ethyl 2,3-dimethyl-2-butenoate (9). Ethyl $\alpha$-(diethoxyphosphinyl)propionate $(243.3 \mathrm{~g})$ was added dropwise to a suspension of sodium hydride $(50.5 \mathrm{~g}$ as $50 \%$ oil dispersion) in dry benzene $(500 \mathrm{ml})$ at room temperature, and then the solution was stirred for $30 \mathrm{~min}$.

Acetone $(47 \mathrm{~g})$ in benzene $(300 \mathrm{ml})$ was added dropwise to the above ice-cooled solution and the solution was stirred for $1 \mathrm{hr}$ at room temperature. The bath temperature was raised slowly to $50^{\circ} \mathrm{C}$ in $1 \mathrm{hr}$ and the solution was stirred for an additional $1 \mathrm{hr}$ at $50^{\circ} \mathrm{C}$. After standing overnight at room temperature the solution was poured into water and extracted with ether. The extract was washed with water three times, dried over $\mathrm{MgSO}_{4}$ and concentrated. The residue was distilled to give $64.2 \mathrm{~g}$ of 9 $(56 \%)$, bp $74 \sim 75^{\circ} \mathrm{C}(45 \mathrm{mmHg}) ; n_{\mathrm{D}}^{22} 1.4416 ; \mathrm{IR} v_{\max } \mathrm{cm}^{-1}$; 1720, 1640; PMR (60 MHz, $\left.\mathrm{CCl}_{4}\right) \delta: 1.3(3 \mathrm{H}, \mathrm{t}, J=7 \mathrm{~Hz}$, $\left.\mathrm{CO}_{2} \mathrm{CH}_{2} \mathrm{CH}_{3}\right), 1.85\left(6 \mathrm{H}, \mathrm{s},\left(\mathrm{CH}_{3}\right)_{2} \mathrm{C}=\mathrm{C}\right), 2.0(3 \mathrm{H}, \mathrm{s}$ $\left.\mathrm{C}=\mathrm{C}\left(\mathrm{CH}_{3}\right) \mathrm{CO}_{2} \mathrm{Et}\right), 4.15\left(2 \mathrm{H}, \mathrm{q}, J=7 \mathrm{~Hz}, \mathrm{CO}_{2} \mathrm{CH}_{2} \mathrm{CH}_{3}\right)$

2,3-Dimethyl-2-butene-1-ol (10). The ester $9(61.5 \mathrm{~g})$ in ether $(330 \mathrm{ml})$ was added dropwise to an ice-cooled solution of lithium aluminum hydride $(13.1 \mathrm{~g})$ in ether $(330 \mathrm{ml})$ under stirring. The mixture was left to stand overnight at room temperature and then heated under reflux for $2 \mathrm{hr}$. After cooling, water $(13 \mathrm{ml}), 15 \% \mathrm{NaOH}$ aq $(13 \mathrm{ml})$, and water $(40 \mathrm{ml})$ were added to the stirred and ice-cooled mixture. 
After stirring for $1 \mathrm{hr}$ THF (300 ml) was added and the mixture was stirred for $30 \mathrm{~min}$. Then it was filtered and the filter cake was washed with THF three times. The combined organic solution was dried over $\mathrm{Na}_{2} \mathrm{SO}_{4}$ and concentrated. The residue was distilled to give $40.2 \mathrm{~g}$ of 10 $(92 \%), n_{\mathrm{D}}^{22} 1.4549$; IR $v_{\max } \mathrm{cm}^{-1}: 3600 \sim 3100,1660,1005$; PMR (100 MHz, CDCl $): 1.65\left(3 \mathrm{H}, \mathrm{s}, \mathrm{CH}_{3}\right), 1.70(6 \mathrm{H}, \mathrm{s}$, $\left.\mathrm{CH}_{3} \times 2\right), 4.1\left(2 \mathrm{H}, \mathrm{s}, \mathrm{CH}_{2}\right)$.

\section{1-Bromo-2,3-dimethyl-2-butene (11)}

From allylalcohol 10. Phosphorus tribromide $(2 \mathrm{~g})$ in dry ether $(7 \mathrm{ml})$ was added dropwise to alcohol $(10.2 \mathrm{~g})$ in dry ether $(10 \mathrm{ml})$ at $-10^{\circ} \mathrm{C}$ under stirring. After 4 hours the mixture was poured into ice-water and was extracted with ether. The extract was washed with water, saturated sodium bicarbonate solution, water and dried over $\mathrm{MgSO}_{4}$. The solution was concentrated in vacuo to give $1.3 \mathrm{~g}(40 \%)$ of 11, IR $v_{\max } \mathrm{cm}^{-1}: 1660,1460 ;$ PMR (100 $\left.\mathrm{MHz}, \mathrm{CCl}_{4}\right) \delta: 1.75\left(3 \mathrm{H}, \mathrm{s}, \mathrm{CH}_{3}\right), 1.80\left(6 \mathrm{H}, \mathrm{s}, \mathrm{CH}_{3} \times 2\right), 4.0$ $\left(2 \mathrm{H}, \mathrm{s}, \mathrm{CH}_{2}\right)$.

From 2,3-dimethyl-2-butene. The mixture of 2,3dimethyl-2-butene $(100 \mathrm{~g}), \mathrm{N}$-bromosuccinimide $(211.5 \mathrm{~g})$, benzoylperoxide $(1 \mathrm{~g})$ and $\mathrm{CCl}_{4}(250 \mathrm{~g})$ was stirred at $70^{\circ} \mathrm{C}$ overnight. The mixture was filtered and the filtrate was concentrated and distilled to give $10.6 \mathrm{~g}$ of $11(36.5 \%)$, bp $60 \sim 62.5^{\circ} \mathrm{C}(36 \mathrm{mmHg}$ ). This bromide was purified by fractional distillation. bp $53.5 \sim 53.9 \mathrm{C}(28 \mathrm{mmHg}), n_{\mathrm{D}}^{22}$ 1.4946 .

This bromide was spectroscopically (IR and PMR) identical with that prepared from allylacohol $\mathbf{1 0}$.

3,4-Dimethyl-3-pentenenitrile (12). Sodium cyanide $(31.6 \mathrm{~g})$ was added to the bromide $11(6 \mathrm{~g})$ in DMSO $(40 \mathrm{ml})$ and the mixture was stirred for $30 \mathrm{~min}$ at $50^{\circ} \mathrm{C}$. The mixture was left to stand overnight at room temperature and poured into ice-water. The solution was extracted with methylene chloride and the extract was washed with water and dried over $\mathrm{MgSO}_{4}$. The extract was concentrated and distilled to give $1.74 \mathrm{~g}(43.3 \%)$ of 12 , bp $77 \sim 80^{\circ} \mathrm{C}(33 \mathrm{mmHg}) ; n_{\mathrm{D}}^{22}$ 1.4489; IR $v_{\max } \mathrm{cm}^{-1}: 2240$, 1440,1420 ; PMR $\left(100 \mathrm{MHz}, \mathrm{CCl}_{4}\right) \delta: 1.70(6 \mathrm{H}, \mathrm{s}$, $\left.\mathrm{CH}_{3} \times 2\right), 1.80\left(3 \mathrm{H}, \mathrm{s}, \mathrm{CH}_{3}\right), 3.0\left(2 \mathrm{H}, \mathrm{s}, \mathrm{CH}_{2}\right)$.

2-Isopropyl-3,4-dimethyl-3-pentenenitrile (13). The nitrile $12(1.0 \mathrm{~g})$ in $4 \mathrm{ml}$ dry benzene was added to lithium hexamethyldisilyl amide in benzene $(30 \mathrm{ml})$ (prepared from hexamethyldisilazane $(1.77 \mathrm{~g})$ and $n-\mathrm{BuLi}(6 \mathrm{ml}$, $1.84 \mathrm{M})$ at $10^{\circ} \mathrm{C}$ ) and the mixture was stirred at $10^{\circ} \mathrm{C}$ for $2 \mathrm{hr}$. Isopropyl bromide $(2.25 \mathrm{~g})$ in benzene $(10 \mathrm{ml})$ was added to the above ice-cooled solution and the mixture was stirred at room temperature overnight. The solution was washed with water, $2 \% \mathrm{HCl}$ aq soln, water and dried over $\mathrm{MgSO}_{4}$. Evaporation of the solvent gave $1.23 \mathrm{~g}(89 \%)$ of 18, $n_{D}^{22} 1.4535 ;$ IR $v_{\max } \mathrm{cm}^{-1}: 2230,1460$; PMR $\left(100 \mathrm{MHz}, \mathrm{CCl}_{4}\right.$ ) $\delta: 0.85$ and 1.2 (each $3 \mathrm{H}, \mathrm{d}, J=6 \mathrm{~Hz}$, $\left.\mathrm{C}\left(\mathrm{CH}_{3}\right)_{2}\right), 1.75\left(9 \mathrm{H}, \mathrm{s},\left(\mathrm{CH}_{3}\right)_{2} \mathrm{C}=\mathrm{CCH}_{3}\right), 1.95(1 \mathrm{H}, \mathrm{m}$, $\left.\mathrm{CHMe}_{2}\right), 3.2(1 \mathrm{H}, \mathrm{d}, J=10 \mathrm{~Hz}, \mathrm{CHCN})$; MS $m / e: 151$
$\left(\mathrm{M}^{+}\right)$

2-Isopropyl-3,4-dimethyl-3-pentenoic acid (14). A mixture of the nitrile $13(900 \mathrm{mg})$, potassium hydroxide $(1.5 \mathrm{~g})$ and ethylene glycol $(5 \mathrm{ml})$ was heated at $140^{\circ} \mathrm{C}$ under stirring for $20 \mathrm{hr}$. The solution was poured into water and washed with ether, and the aqueous layer was acidified with $5 \% \mathrm{HCl}$ aq soln. The aqueous solution was extracted with ether three times and the extract was dried over $\mathrm{Na}_{2} \mathrm{SO}_{4}$. Evaporation of the solvent gave $420 \mathrm{mg}(41.5 \%)$ of $14, n_{\mathrm{D}}^{20} 1.4663 ;$ IR $v_{\max } \mathrm{cm}^{-1}: 3000 \sim 2500,1705$, 940; PMR (100 MHz, $\left.\mathrm{CDCl}_{3}\right) \delta: 0.75$ and 1.0 (each $3 \mathrm{H}, \mathrm{d}$, $\left.J=7 \mathrm{~Hz}, \mathrm{C}\left(\mathrm{CH}_{3}\right)_{2}\right), 1.6\left(3 \mathrm{H}, \mathrm{s}, \mathrm{CH}_{3}\right), 1.68\left(3 \mathrm{H}, \mathrm{s}, \mathrm{CH}_{3}\right)$, $1.76\left(3 \mathrm{H}, \mathrm{s}, \mathrm{CH}_{3}\right), 2.1\left(1 \mathrm{H}, \mathrm{m}, \mathrm{CHMe}_{2}\right), 3.1(1 \mathrm{H}, \mathrm{d}, J=11$ $\mathrm{Hz}, \mathrm{CHCOOH}), 10.1$ (1H, bs, $\mathrm{COOH})$.

The acids $1,2,3,5,6$ and 14 were converted to the corresponding acyl chlorides and esterified with 3phenoxybenzyl alcohol by the usual method to give the esters $15,16,17,18$, and 19 . The products were purified by silica-gel chromatography.

3-Phenoxybenzyl 2-(2,2-dichloro-3-methylcyclopropyl)3 -methylbutyrate (20). The ester $\mathbf{1 6}(2 \mathrm{~g})$ was added to the solution of benzyltriethylammonium chloride $(0.2 \mathrm{~g})$ in chloroform $(30 \mathrm{ml})$ under stirring and then $50 \% \mathrm{NaOH}$ aq soln $(20 \mathrm{ml})$ was added to the mixture at room temperature. The solution was stirred for $72 \mathrm{hr}$ at room temperature. Then the solution was poured into water and the chloroform layer was washed with dil $\mathrm{HCl}$, brine and dried over $\mathrm{MgSO}_{4}$. The solvent was evaporated and the residue was chromatographed on silica gel ( $n$-hexane) to give $2.10 \mathrm{~g}(83.6 \%)$ of the dichloride $20, n_{\mathrm{D}}^{25} 1.5412$; IR $v_{\max } \mathrm{cm}^{-1}: 3070,3040,1740 ;$ PMR $\left(60 \mathrm{MHz}, \mathrm{CCl}_{4}\right) \delta$ : $0.95\left(6 \mathrm{H}, \mathrm{d}, J=6 \mathrm{~Hz}, \mathrm{C}\left(\mathrm{CH}_{3}\right)_{2}\right), 1.3\left(3 \mathrm{H}\right.$, bs, $\left.\mathrm{CH}_{3}\right)$, $1.7 \sim 2.4(4 \mathrm{H}, \mathrm{m}, \mathrm{CH} \times 4), 5.15\left(2 \mathrm{H}, \mathrm{s}, \mathrm{CH}_{2}\right), 6.8 \sim 7.6(9 \mathrm{H}$, $\mathrm{m}, \mathrm{PhH})$.

3-Phenoxybenzyl 2-(2.2-dichloro-3-ethylcyclopropyl)-3methylbutyrate (21). The ester $17(1 \mathrm{~g})$, benzyltriethylammonium chloride $(0.1 \mathrm{~g}), \mathrm{CHCl}_{3}(15 \mathrm{ml})$ and $50 \%$ $\mathrm{NaOH}$ aq soln $(10 \mathrm{ml})$ were treated as described for $\mathbf{2 0}$ to give $0.85 \mathrm{~g}(68.2 \%)$ of $21, n_{\mathrm{D}}^{25} 1.5404 ; \mathrm{IR} v_{\max } \mathrm{cm}^{-1}: 1740$; PMR $\left(60 \mathrm{MHz}, \mathrm{CCl}_{4}\right) \dot{\delta}: 0.9 \sim 1.3\left(9 \mathrm{H}, \mathrm{m}, \mathrm{CH}_{3} \times 3\right)$, $1.4 \sim 2.3\left(6 \mathrm{H}, \mathrm{m}, \mathrm{CH} \times 4\right.$ and $\left.\mathrm{CH}_{2} \mathrm{CH}_{3}\right), 5.15\left(2 \mathrm{H}, \mathrm{s}, \mathrm{CH}_{2}\right)$, $6.8 \sim 7.6(9 \mathrm{H}, \mathrm{m}, \mathrm{PhH})$.

3-Phenoxybenzyl 2-isopropyl-3,4-epoxypentanoate (22). Ice-cooled $m$-chloroperbenzoic acid $(0.8 \mathrm{~g})$ in dichloromethane $(15 \mathrm{ml})$ was added to a mixture of the ester $\mathbf{1 6}$ ( $\mathrm{g}$ ), sodium bicarbonate $(0.75 \mathrm{~g})$ and $\mathrm{Na}_{2} \mathrm{HPO}_{4}(0.15 \mathrm{~g})$ in dichloromethane $(10 \mathrm{ml})$ under stirring. After the mixture was stirred overnight at room temperature, sat. sodium bicarbonate was added to the solution and the solution was extracted with dichloromethane. The extract was washed with sodium bicarbonate soln, brine and dried over $\mathrm{MgSO}_{4}$. The solvent was evaporated and the residue was chromatographed on silica gel (Mallinkrodt $\mathrm{CC}$-7) 
(benzene-ether $3: 1)$ to give $0.93 \mathrm{~g}(89 \%)$ of the epoxide 22 , $n_{\mathrm{D}}^{25}$ 1.5353; PMR (60 MHz, $\left.\mathrm{CCl}_{4}\right) \delta$ : 0.88 and 0.99 (each $\left.3 \mathrm{H}, \mathrm{d}, J=3 \mathrm{~Hz}, \mathrm{C}\left(\mathrm{CH}_{3}\right)_{2}\right), 1.25\left(3 \mathrm{H}, \mathrm{d}, J=6 \mathrm{~Hz}, \mathrm{CCH}_{3}\right)$, $1.5 \sim 2.5\left(2 \mathrm{H}, \mathrm{m}, \mathrm{CHCO}_{2}\right.$ and $\left.\mathrm{CHMe}_{2}\right), 2.6 \sim 2.9(2 \mathrm{H}, \mathrm{m}$, $\mathrm{O}$

$\mathrm{HC}-\mathrm{CH}), 5.1\left(2 \mathrm{H}, \mathrm{s}, \mathrm{CH}_{2}\right), 6.5 \sim 7.7(9 \mathrm{H}, \mathrm{m}, \mathrm{PhH})$.

3-Phenoxybenzyl 2-isopropyl-3,4-epoxyhexanoate (23). Phenoxybenzyl hexenoate $(17,1 \mathrm{~g})$ and $m$-chloroperbenzoic acid $(0.8 \mathrm{~g})$ were treated as described for 22 to give $0.92 \mathrm{~g}(88 \%)$ of $23, n_{\mathrm{D}}^{25} 1.5313$; IR $v_{\max } \mathrm{cm}^{-1}: 1740,1590$, $1490,1275,1230,900,700$; PMR $\left(60 \mathrm{MHz}, \mathrm{CCl}_{4}\right) \delta$ : $0.8 \sim 1.1\left(9 \mathrm{H}, \mathrm{m}, \mathrm{CH}_{3} \times 3\right), 1.2 \sim 2.1\left(4 \mathrm{H}, \mathrm{m}, \mathrm{CH}_{2} \mathrm{CH}_{3}\right.$, $\mathrm{CHCO}_{2}$ and $\left.\mathrm{CHMe}_{2}\right), 2.4 \sim 2.9(2 \mathrm{H}, \mathrm{m}, \mathrm{HC}-\mathrm{CH}), 5.1$ $\mathrm{O}^{\prime}$ $\left(2 \mathrm{H}, \mathrm{s}, \mathrm{CH}_{2}\right), 6.6 \sim 7.7(9 \mathrm{H}, \mathrm{m}, \mathrm{PhH})$.

\section{REFERENCES}

1) M. Matsui and I. Yamamoto, "Naturally Occurring Insecticides," ed. by M. Jacobson and D. J. Crosby, Marcel Dekker, Inc., New York, N.Y., 1971, p. 3.

2) N. Ohno, K. Fujimoto, Y. Okuno, T. Mizutani, M. Hirano, N. Itaya, T. Honda and H. Yoshioka, Agric. Biol. Chem., 38, 881 (1974).

3) R. P. Linstead, E. G. Noble and E. J. Boorman, J. Chem. Soc., 1933, 557.

4) T. Matsuo, K. Mori and M. Matsui, Tetrahedron Letters, 1976, 1979. 